\title{
食品中の非金属異物検出のための $\mathrm{CdTe}$ 素子センサ による透過 X 線スペクトル解析
}

小川幸春* · 守田和夫** ・田中俊一郎 ${ }^{* *} \cdot$ Chi N. THAI**

\author{
X-ray Spectral Analysis with CdTe Sensor for Detection of \\ Foreign Materials in Food
}

\author{
Yukiharu OgawA*, Kazuo MoRITA**, Shun-ichiro TANAKA ${ }^{* *}$ \\ and Chi N. THAI*** \\ * United Graduate School of Agricultural Sciences, Kagoshima University, \\ 1-21-24, Korimoto, Kagoshima, 890 \\ ** Faculty of Agriculture, Kagoshima University, 1-21-24, Korimoto, Kagoshima, 890 \\ *** College of Agricultural \& Environmental Sciences, The University of \\ Georgia, Athens, GA 30602-4435 U.S.A.
}

\begin{abstract}
The potential for detection of non-metallic foreign materials in food using $\mathrm{X}$-ray spectral analysis method was discussed. X-ray measuring system with CdTe crystal sensor was developed and X-ray spectrum of food could be measured and analyzed. X-ray linear absorption coefficients $(\mu)$ at each $\mathrm{X}$-ray photon energy level of various materials were calculated from $\mathrm{X}$-ray spectra. As the $\mu$ value was shown a function of X-ray characteristic of material, it was considered to be valid for detection of foreign material in food. The vinyl chloride plate in distilled water was investigated as a simple model. The percentage and different type of foreign materials in uniform sample could be estimated by measurement of peek position of derivative $\mathrm{X}$-ray spectrum. The $\mathrm{X}$-ray spectrum measuring system was then tried to be applied for detection of foreign materials in food. Three samples of hamburger patty, one free of foreign materials and two with foreign materials (glass and vinyl chloride) were tested. Peek position of derivative $\mathrm{X}$-ray spectrum at hamburger patty without foreign materials was $15.5 \mathrm{keV}$ and that at hamburger patty with glass and vinyl chloride plate moved to 17.5 and $17.0 \mathrm{keV}$, respectively. These results showed that, the $\mathrm{X}$-ray spectrum analysis method has potential and can be applied in detecting non-metallic foreign materials in food with a proper threshold value at derivative $\mathrm{X}$-ray spectrum. However, in practical use, the effect of thickness, mixing material and unevenness of material have to considered in the $\mathrm{X}$-ray measurement. It is expected that different types of non-metallic foreign materials in various kinds of foods could be automatically detected by the X-ray spectrum measuring system with CdTe crystal sensor.
\end{abstract}

(Received May 29, 1997 ; Accepted Sep. 16, 1997)

食品の製造, 加工および流通分野において, 食品の品 質を確保し，消費者に安全性の高い製品を供給すること は重要な課題である. 国内では 1995 年 7 月に施行され
た製造物責任法（PL 法）や1995 年 4 月に改正された食 品衛生法など法的規制も加わり，安全対策の重要性が再 認識されている. 国際的にも 1994 年に日本の加盟が批

\footnotetext{
* 鹿児島大学大学院連合農学研究科（干890 鹿児島市郡元 1-21-24）

** 鹿児島大学農学部（干890 鹿児島市郡元 1-21-24）

****ショージ大学農業および環境学部 (Athens, GA 30602-4435 U.S.A.)
} 
准された世界貿易機関（WTO）で製品の規格や HACCP, ISO 9000 シリーズなどによる製造工程の衛生 管理対策が強く求められてきているい

1996 年の病原性大腸菌 O-157 による食中毒は社会的 問題に発展し，農産物や食品には従来以上の安全対策が より必要になってきている．農産物や食品の女全性を確 保するための検查は，検出対象によって大きく微生物污 染を対象とする生物学的検查, 薬品や化学添加物などを 対象とする化学的検查、プラスティック片，金属片など の異物を対象とする物理学的検查の 3 種類に分類され る2).なかでも物理学的検查は混入する異物の種類，大 きさおよび混入状热が一定でないため，統計的な手法を 用いたサンプリング検查では対応できないのが現状であ る、したがって非破壊での全量検查が必要であることか ら，金属検出機やフォトダイオードアレイなどを用いた $\mathrm{X}$ 線検出システムが用いられている32。このうち金属検 出機は限られた金属異物しか検出できないという久点を 持つため4)，沉用性の高いX 線を利用した検出システム が研究, 開発されている5)，しかしX線を利用する現行 の手法は透過 $\mathrm{X}$ 線強度の湘定が主体であり，物質の分 光的な X 線吸収特性の違いなどが考虑されていないた め，異物の種類，特に非金属異物に対する検出感度に限 界があり，より確実な検出技術の開発が望まれている゙5.

本研究は, $\mathrm{CdTe}$ 素子センザ7) とマルチチャンネル アナライザを組み合わせた X 線スペクトル計測システ ムを構筑し，対象物を透過したX線スペクトルの測定 および解析を行うことにより，今まで検出が難しいとさ れていた食品中に混入する非金属異物の検出の可能性に ついて検討したものである.

\section{$\mathrm{X}$ 線スペクトル計測システム搆筑のための基本的概念}

$\mathrm{X}$ 線は赤外線や可視光線などと同じ電磁波であるが， 波長が原子の大きさより小さいために物体を容易に透過 する性質を持つ、X線の波長域はおよそ10 nm から $0.01 \mathrm{~nm}$ で, 発生の段階で単一波長の特性 X 線と連続し た波長域の連続 X 線に分類されている92. 物質を透過す るX線の割合は，長波長領域より短波長領域のほうが 大きいので，連続 X 線が物体を透過するとき，透過後に 計測されるX線スペクトルは短波長領域の占める割合 が多くなる．この現象は線質硬化現象之呼ばれており， 長波長域のX線中で顕著な現象として現れ，X線 CT などの計測装置では測定データ補正の対象となってい $3^{(0)}$.

物質を透過したX $\mathrm{X}$ 線の強度は (1) 式によって表わさ
れ，X 線が透過する距離 $(l)$ と物質の X 線線吸収係数

(u) によって決定される。

$\mathrm{I}=\mathrm{I}_{0} \cdot \exp (-\mu \cdot l)$

ここで,

$\mathrm{I}$ : 透過 X 線強度 (photon $\cdot \mathrm{mm}^{-2} \cdot \mathrm{s}^{-1}$ )

$\mathrm{I}_{0}:$ 入射 $\mathrm{X}$ 線強度 (photon $\cdot \mathrm{mm}^{-2} \cdot \mathrm{s}^{-1}$ )

$\mu: \mathrm{X}$ 線吸収係数 $\left(\mathrm{mm}^{-1}\right)$

$l: \mathrm{X}$ 線透過厚 $(\mathrm{mm})$

$\mathrm{X}$ 線線吸収係数 $(\mu)$ は (2) 式で表わされ，X 線質量吸 収係数 $\left(\mu_{0}\right)$ と物質のかさ密度 $(\rho)$ の関数として与えら れる。

$\mu=\mu_{0} \cdot \rho$ ここで

$\mu:$ 物質の $\mathrm{X}$ 線線吸収係数 $\left(\mathrm{mm}^{-1}\right)$

$\mu_{0}$ : 物質の $X$ 線質量吸収係数 $\left(\mathrm{mm}^{2} \cdot \mathrm{g}^{-1}\right)$

$\rho:$ 物質のかさ密度 $\left(\mathrm{g} \cdot \mathrm{mm}^{-3}\right)$

$\mu_{0}$ は物質を構成する元素の原子番号に比例する固有の 值であり，物質の状態によらない值として与えられる. したがって透過 X 線の強度は，透過厚さ，物質を構成す る元素の原子番号および物質のかさ密度によって变化す ろ.

X 線をエネルギを持つ光子の集まりと考えると，その 波長は (3) 式を用いてェネルギレベル（keV）で表わさ れ、拈よそ $0.1 \mathrm{keV}$ から $100 \mathrm{keV}$ の範囲にある。

$$
E=\frac{1.24}{\lambda}
$$
ここで,

$$
E: エ ネ ル キ ゙ レ ヘ ゙ ル （ \mathrm{keV})
$$

$\lambda:$ 波長 $(\mathrm{nm})$

本実験では，X 線光子を計測しているため，X 線の波長 を(3)式にしたがってエネルギレベル（keV）として表し た.

\section{実験装置および方法}

\section{X 線発生装置および検出器}

$\mathrm{X}$ 線発生装置は可変出力型の $\mathrm{M}-80 \mathrm{WE}$ 特型 （SOFTEX CO., LTD）を使用したＸ X 線管球（I-1310： SOFTEX CO., LTD）は対陰極がタングステン，放射空 は金属べリリウム膜で，連続 X 線を発生し，空気中でお よそ $6 \mathrm{keV}$ 以上の X 線の放射が可能である.

$\mathrm{X}$ 線の検出には X 線光子の計測が可能な CdTe 素子 センサを使用し，X 線スペクトルを測定するためにマル チチャンネルアナライザを用いた．CdTe素子センサに より計測されたX X線光子は，アナログ信号に変換され， 增幅器（CT 571 型: TOYO MEDIC CO., LTD）を用い 
て増幅後, マルチチャンネルアナライザ（S 5000 MCArd : APTEC ENGINEERING LTD.) によって $\mathrm{AD}$ 変換され, $\mathrm{X}$ 線光子の持つエネルギ别に 1024 段階 のエネルギレベルの一つに振り分けられる．X線強度は 各エネルギレヘルごとに計測された単位時間，単位面積 当たりの X 線光子数で示し，測定された $\mathrm{X}$ 線強度をエ ネルギレベルことに連統的に表すことで X 線スペクト ルを表示した. マルチチャンネルアナライザにより分割 されたエネルギレベルの校正は校正用放射線源 $\left(\mathrm{Co}^{57}\right)$ により行われ，構築したX線スペクトル計测システム の各エネルギレベルおたりの分解能は約 $0.1 \mathrm{keV}$, 半値

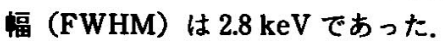

\section{2. 測定方法}

Fig. 1 は X 線計測部の概略図である. 本実験に使用し た X 線嫄は発散線源であることから，図に示すように $\mathrm{X}$ 線管球よ $\mathrm{CdTe}$ 素子七ンサを結ぶ直線上に湘定対象 物を眍置し，対象物を透過したX 線のみを計測できる ようにした．また，本実験では CdTe 素子センサの検出 面の直径は $0.2 \mathrm{~mm}$ を採用した。

\section{3. 測定対象物}

X線スペクトル計測システムの基礎特性を調べるた め,アクリル樹脂，ガラス，塩化ビニルのプレートおよ び烝留水を测定対象物として実験を行った．また，食品 中の異物検出の可能性を調へるため, 加工食品に対する 異物混入のモデルとして，市販のハンパーグに異物とし てガラスおよび塩化ビニルのプレートを挿入し，検出を 試みた。使用した X 線測定対象物の密度および化学式 は Table 1 に示す.

\section{実験結果およひ考察}

\section{X 線スペクトル}

$\mathrm{X}$ 線計測システムの测定条件および安定性を検討す るために空気中での X 線スペクトルの計測を行った.

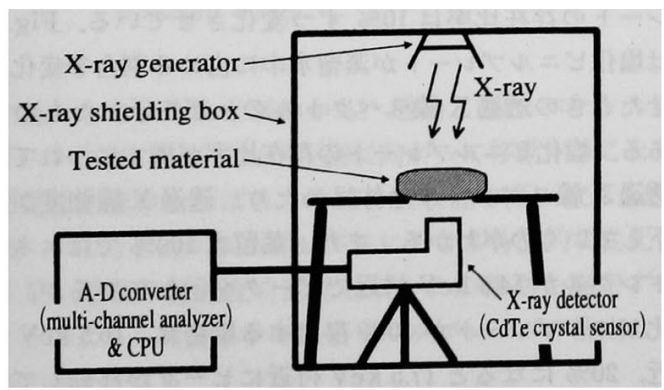

Fig. 1 Schematic diagram of experimental apparatus
Fig. 2 は X 線源と CdTe 素子センサの距離を $360 \mathrm{~mm}$ に固定し，X線源出力を変化させたときの X 線スペク トルを示したあのである，横軸は X 線のエネルギレベ ル，縦軸は X 線強度を表している．X 線のエネルギレべ ルが $10 \mathrm{keV}$ から $20 \mathrm{keV}$ の範囲では, $\mathrm{X}$ 線源の出力電 圧を上げるにつれて X 線強度は増大し，X線スペクト ルも全体的に上昇した. Fig. 3 は X 線源出力を管電圧 $20 \mathrm{kV}$, 管電流 $0.5 \mathrm{~mA}$ に固定し, $\mathrm{X}$ 線源と $\mathrm{CdTe}$ 素子七 ンサの距離を変化させた場合の X 線スペクトルを示し たものである．X 線源と $\mathrm{CdTe}$ 素子センサ間の距離が長 くなるにつれて X 線強度は減少し，X線スペクトルは 全体的に下降した．これらの現象は X 線管球の電圧す なわち加速電子速度の違いにより，タングステンから放 出される X 線光子の持つエネルギの分布が異なるため, また，空気層によるX線の減衰のために起こるもので ある.このように，計測された X 線スぺクトルは X 線 源の出力ゃ $\mathrm{X}$ 線源と $\mathrm{CdTe}$ 素子センサの距離によって

Table 1 Density and chemical formula for tested materials

\begin{tabular}{lcc}
\hline \hline \multicolumn{1}{c}{ Material } & $\begin{array}{r}\text { Density, } \\
\mathrm{g} / \mathrm{m} l\end{array}$ & Chemical formula \\
\hline Glass plate & 2.81 & $\mathrm{SiO}_{2}$ \\
Acrylic plate & 1.26 & {$\left[-\mathrm{CH}_{2}-\mathrm{CH}(\mathrm{CN})-\right]_{\mathbf{n}}$} \\
Vinyl chloride plate & 1.25 & {$\left[-\mathrm{CH}_{2}-\mathrm{CHCl}-\right]_{\mathbf{n}}$} \\
Distilled water & 1.00 & $\mathrm{H}_{2} \mathrm{O}$ \\
Hamburger patty & 1.19 & - \\
\hline
\end{tabular}

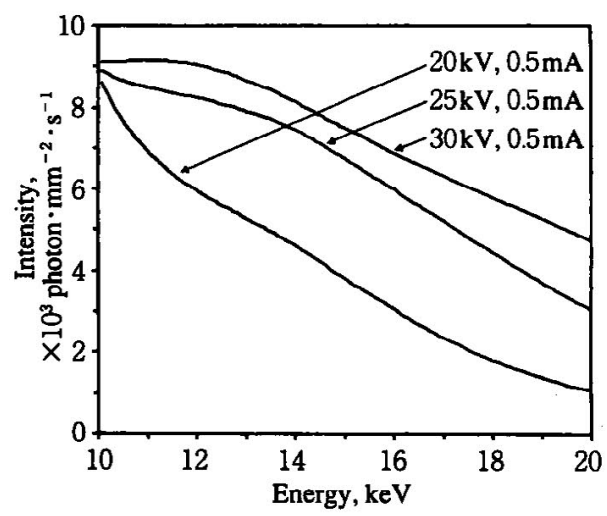

Fig. 2 Spectra for different power level of continuous $\mathrm{X}$-ray at the distance of 360 $\mathrm{mm}$ between $\mathrm{X}$-ray source and detector 
変化するため，本実験では $\mathrm{X}$ 線源出力を管電圧 $20 \mathrm{kV}$, 管電流 $0.5 \mathrm{~mA}, \mathrm{X}$ 線源と CdTe 素子センサの距離を $360 \mathrm{~mm}$ に固定した一定条件下で行った．また，繰り返 し测定を行ってもX線スペクトルの形状およびX 線強 度に大きな变化は見られなかったので，本計湘システム は安定性および再現性の高いものと判断された。

\section{2. 異なる素材の X 線線吸収係数}

$\mathrm{X}$ 線の透過特性を検討するため，異なる材質の対象物 を使って透過 X 線スペクトルを湖定し，エネルギレベ ルことの X 線線吸収係数を求めた. Fig. 4 はガラス, 丁 クリル，塩化ビニルのプレートおよび蒸留水を対象物と

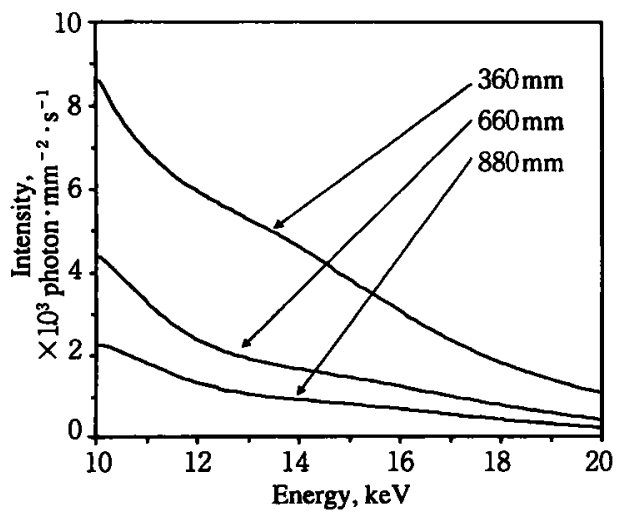

Fig. 3 Spectra for different distance between $\mathrm{X}$-ray source and detector at X-ray condition of $20 \mathrm{kV}, 0.5 \mathrm{~mA}$

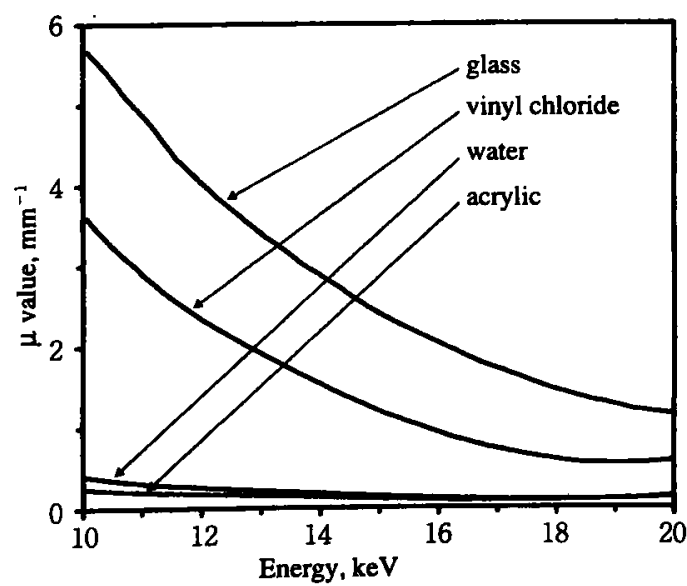

Fig. 4 Calculated X-ray linear absorption coefficients $(\mu$ value) at each energy levels for different types of material
して透過 X線スペクトルの計湘を行い，エネルギレベ ルごとの線吸収係数 $\mu$ の変化を計算したあのである. 計 算にはェネルギレベルことに(1)式を用いて $\boldsymbol{\mu}$ 值を算出 し，図は横軸にエネルギレベル，緃軸に $\mu$ 值を示した。 Table 1 の化学式に示したように坦化ビニルプレートは 比较的原子番号の大きい塩素 $(\mathrm{Cl})$, ガラスプレートはけ い素（Si）を含むことから $\mu$ 值も他の対象物に比べて大 きな值を示した，全体的な㑯向としてェネルギレベルが 大きくなるほど各対象物の $\mu$ 值は減少した. すなわち， $\mathrm{X}$ 線線吸収係数の推移は対象物固有の X 線吸収特性を 示し，透過 X線スペクトルから見て，エネルギレベルが 小さくなるほどその変化が大きく異なっていることがわ かる.

このように, $\mu$ 值から見て测定対象物の X 線吸収特性 侥成原子，かさ密度の違いにより異なるので，この性 質を利用することにより異物検出が可能であると考えら れる. しかし，実際の食品は複合材料が混在しているの で，食品を透過したX線の吸収特性は全ての素材の $\mu$ 値が重なって計测される．食品中に含まれる異物の検出 にX 線を適用するためには，様々な物質が混在した複 合状態での X 線の吸収特性を検討することが必要であ る.

\section{3. 䙓合モデル中の X 線吸収特性}

食品を構成する物質のなかで，最も多く含まれている あのは水分である，簡単のために均質な材料中の異物を 検出することを目的に，食品のモデルとして蒸留水，異 物のモデルとして塩化ビニルプレートを用いて基本的な X 線吸収特性に関するモデル実験を行った．実験は Fig. 5 に示すようにX 線が材料を透過する厚さを常に一定 に保ち，蒸留水中の塩化ビニルブレートの存在比率を変 化させたときの透過 X 線スぺクトルの変化を测定した. $\mathrm{X}$ 線が透過する厚さは $5.0 \mathrm{~mm}$ で塩化ビニルプレート 1 枚の厚さは $0.5 \mathrm{~mm}$ であり，蒸留水中の堭化ビニルブ レートの存在比率は $10 \%$ ずっ変化させている．Fig. 6 は塩化ビニルプレートが蒸留水中に占める割合を変化さ せたときの透過 X線スペクトルの一部を示したものて ある. 塩化ビニルプレートの存在比率が增すにつれて, 透過 X 線スペクトル全体にわたり，透過 X 線強度が低 下していくのがわかる. また, 蒸留水 $100 \%$ ではェネル ギレベルが $14.5 \mathrm{keV}$ 付近でピークを示しているが, 塩 化ビニルプレートが $10 \%$ 存在する場合は， $16.5 \mathrm{keV}$ 付 近，20\%になると $17.5 \mathrm{keV}$ 付近にピークが移動してい ろ.さらにエネルギレヘルこととの X 線強度を比较する と, 高エネルギレベルより低エネルギレベルの減少割合 


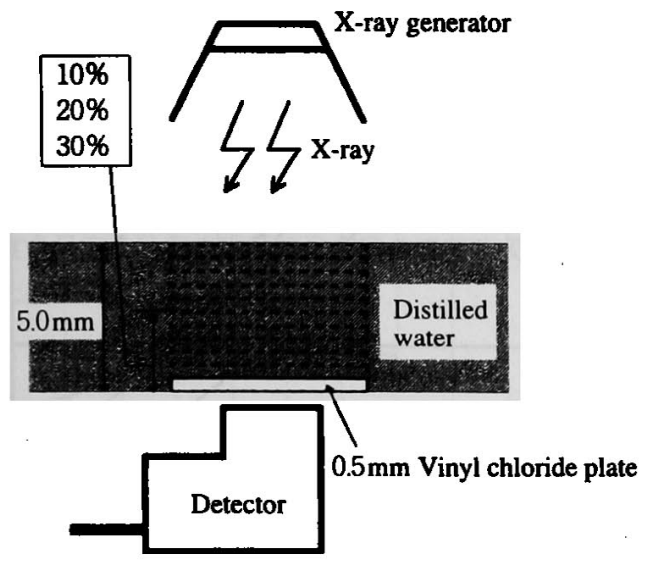

Fig. 5 Schematic diagram of measuring method for the detection of transmitted $\mathrm{X}$-rays through vinyl chloride plates in distilled water

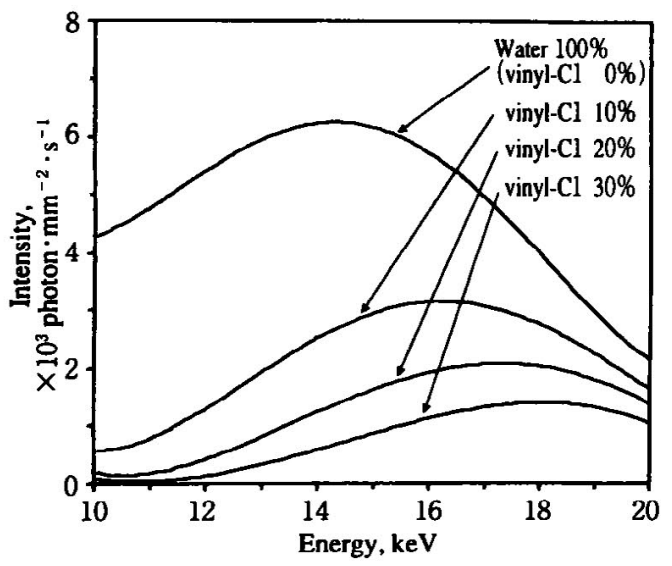

Fig. 6 Transition of spectra of transmitted $\mathrm{X}$-rays through vinyl chloride plates in distilled water

が増大していることがかかる．透過 X線スペクトルの ピークが高エネルギレベル㑡に向かって移動することは 線質硬化現象と呼ばれ，X線の吸収性の高い軟 X 線領 域すなかち低エネルギレベルにおける特徽的な変化で ある. 透過 X 線強度の変化とピークの移動を測定する ことにより, 蒸留水中の塩化ビニルブレートの検出は可 能と考えられる.

4. 異物模出への遮過 $\mathrm{X}$ 線スベクトルの利用 蒸留水之塩化ビニルプレートのモデ実䥒から, 蒸留
水中に塩化ビニルプレートが湿入する割合の違いにより 透過 X線スペクトルのピークは高エネルギレベル側に 移動していくことが判明した．この透過 X 線スペクト ルのピークの移動と透過 X 線強度の変化を異物検出に 適用することを検討した．Fig. 7 は，Fig. 6 の透過 X 線 スペクトルを一次微分した微分スペクトルである．一次 微分することにより, Fig. 6 における透過 X 線スベクト ルのピークが微分值 0 として表わされ，上り明確な変化

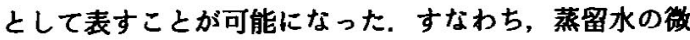
分スペクトルで微分值 0 のエネルギレベル前後で異物検 出のためのしきい值を設定すれば，異物モデルである塩 化ビニルプレートの検出が可能になる.

次に，透過 X線スペクトルによる異物混入割合の検 出を検討するため, 透過 X線スペクトルの移動した ピークでの透過 X 線強度を説明变数に，蒸留水中の塩 化ビニルの存在比率を目的変数として重回㷌分析を行っ た. その結果, 重相関係数は 0.9993 となり, 分散分析よ り重回掃式は有為水準 $1 \%$ で精度良く判定が可能であっ た. 同様の手法で、蒸留水中のガラスプレート，アクリ ルプレートのモデル実験を行い，重回㛿分析を行った結 果，重相関係数はそれぞれ，0.9860，0.9764 となり，いず れも分散分析より重回帰式は有為水準 $1 \%$ で精度良く異 物モデルの混入割合の推定が可能であった.これらのモ テル夷験のように均質材料内の単一異物モデルでは微分 スペクトルの微分值 0 およひ透過 X 線強度から含まれ る異物の割合をも推定が可能である.

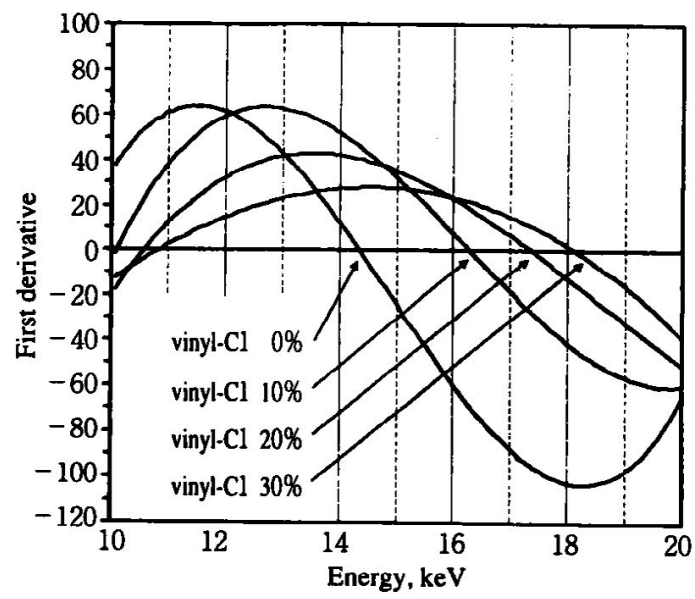

Fig. 7 First derivative spectra of vinyl chloride plates in distilled water 


\section{5. 是品中の非金属暴物の検出への適用}

実際の食品中に異物を挿入してX線スペクトル計測 システムによる異物検出の可能性について検討した，食

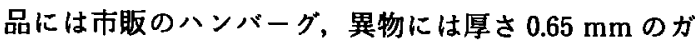
ラスプレートおよび厚さ $0.5 \mathrm{~mm}$ の塩化ビニルプレート を用いて透過 X 線スぺクトルの测定を行った。市販の ハンバーグは厚さが $10 \mathrm{~mm}$ ほどあったので，透過 X 線 強度の調整が必要であった。ここでは X 線源出力は管 電圧 $40 \mathrm{kV}$ ，管電流 $1.5 \mathrm{~mA}$ に変更した。計測された透 過 X 線スペクトルを Fig. 8 に，做分スペクトルを Fig. 9 に示した. ハンバーグのみの場合は，エネルギレベル が $15.5 \mathrm{keV}$ 付近でピークを示し，ガラスプレートをハ ンパーグに挿入した場合は，17.5 keV 付近，塩化ビニル プレートの場合は $17.0 \mathrm{keV}$ 付近でピークを示した。し たがって, 今回の実験ではエネルギレベルが $15 \mathrm{keV}$ か ら $16 \mathrm{keV}$ 付近でしきい值を設定することにより，ハン バーグ内に挿入したガラスプレートおよび塩化ビニルプ レートは微分スペクトルから異物として検出することが 可能である. 実用的には試料厚さが透過 X 線強度に及 ばす影艟や材料の混合状態の違いによる透過 X 線スぺ クトルの変動などを食品素材や異物の種類，大きさに応 じて詳細に検討しなければ，しきい值の決定は難しい。 しかし，湘定する食品が比較的均質で厚さる一定であれ ば，砤分スペクトルから適当なエネルギレベルでしきい 值を設定することにより，非金属異物に対しても検出が 可能であると考えられる.

以上のように，透過 X 線スペクトル手法は食品中の

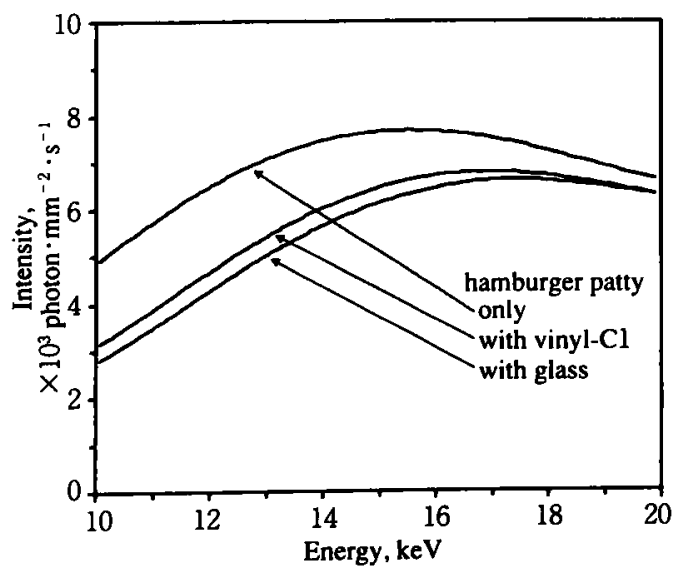

Fig. 8 Spectra of transmitted X-rays through hamburger patty without and with different types of foreign materials

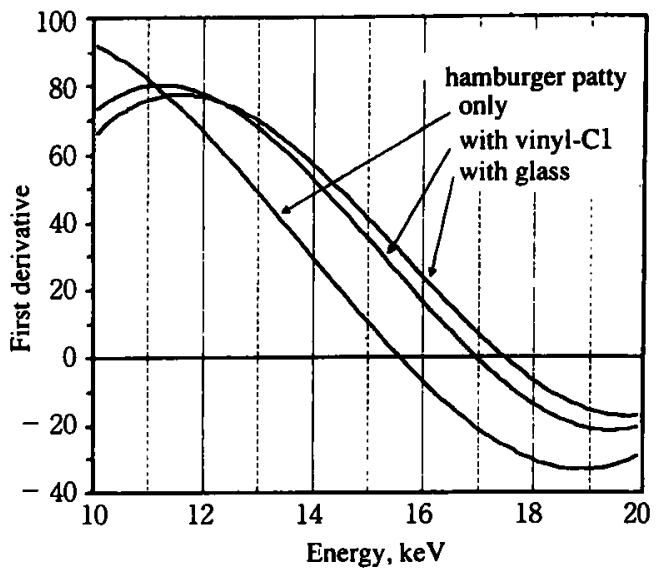

Fig. 9 First derivative spectra of transmitted $\mathrm{X}$-rays through hamburger patty without and with different types of foreign materials

異物検出の有効な手段の一つとして考えられ，この計測 システムを適用したラインセンサおよび専用ソフトウエ アを構勧することにより，X 線吸収特性の異なる食品中 の非金属異物の自動検出の可能性が示された.

$$
\text { 要約 }
$$

透過 X 線スペクトルを利用した食品中の非金属異物 の検出の可能性を検討し，以下の知見を得た.

(1) $\mathrm{CdTe}$ 素子七ンサを使った X 線スペクトル計測 システムを構筑し，透過 X線スペクトルの計湖および 解析が可能になった.

(2) 透過 X線スペクトルからエネルギレベルことの $\mathrm{X}$ 線線吸収係数 $\mu$ の変化が求められ， $\mu$ 值の違いを利用 することにより，異物検出の可能性が示唆された。

（3）蒸留水と塩化ビニルプレートの復合モデルの透過 $\mathrm{X}$ 線スペクトルおよび微分スペクトルを求め，透過 $\mathrm{X}$ 線強度とビークの移動から蒸留水中の壏化ビニルプレー トの検出および混入割合の推定が可能となった。

（4）実際の食品中の異物検出に適用した結果，ハン パーグの微分スペクトルのピークは $15.5 \mathrm{keV}$, ガラスプ レートが混入すると $17.5 \mathrm{keV}$, 塩化ビニルプレートが混 入すると $17.0 \mathrm{keV}$ となり，計測する対象物に合わせた しきい值を設定すれば，異物検出に適用できることが明 らかになった. しかし，実用的には試料厚さの影整や材 料の混合状態の変動などを考虑しなければならない.

（5）透過 X 線スベクトル手法は，X線吸叹特性の異 
なる食品中の異物検出の有効な手段の一つと考えられ， 専用ソフトゥエアの構築により，非金属異物に対する自 動検出の可能性が示された.

本研究の一部は財団法人食品産業センターの平成 6,7 年度食品安全性向上技術開発事業の研究助成により行わ れた。ここに記して謝意を表する.

\section{文献}

1）鈴木 進: 食品工業，38，25（1995）.

2) Morita, K., Tanaka, S., Ogawa, Y., Setoguchi, K. and ThAI, C.N. : ASAE paper No. 966058, Phoenix (1996).

3）剣持庯一：センサ技術，12，54（1992）.
4）竹之内靖方：センサ技術，12，61（1992）.

5）策原八郎: 冷凍, 70, 1207 (1995).

6) Morita, K., Tanaka, S., Ogawa, Y. and Thai, C. N. : ASAE paper No. 966059, Phoenix (1996).

7) OHMORI, M., IWASE, Y. and OHNO, R. : Materials Science and Engineering, B 16, 283 (1993).

8) IWASE, Y., TAKamuRa, H., URATA, K. and OHMORI, M. : Sensors and Actuators, A 34, 31 (1992).

9）菊田星志：X 線回折 - 散乱技術（上），初版（東京 大学出版会, 東京), p. 35 (1992).

10）藤井正司・宇山喜一郎：非破壊検査，43，273 (1994).

(平成 9 年 5 月 29 日受付, 平成 9 年 9 月 16 日受理) 